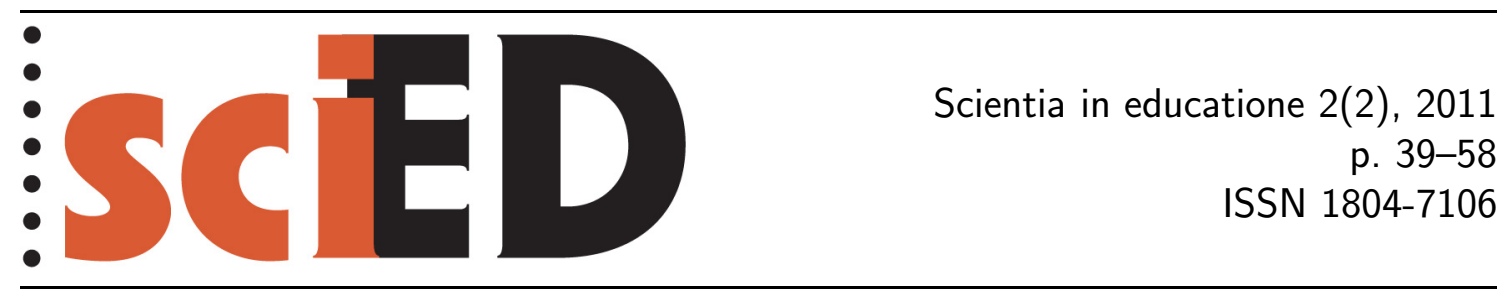

\title{
Žákovské konstrukce poznatků v matematice
}

\author{
Nad’a Stehlíková, Michaela Ulrychová
}

\begin{abstract}
Abstrakt
Článek se věnuje problematice konstrukce poznatků v matematice žáky, konkrétně mechanizmu individuální a společné konstrukce poznatků na př́́kladu znovuobjevování Pythagorovy věty $\mathrm{v}$ prostředí čtverečkovaného papíru. Teoretické pozadí práce sestává z teorie generických modelů a konstruktivistických př́stupů $\mathrm{k}$ výuce matematiky, resp. podnětné výuky. Byl proveden klinický experiment se žáky osmiletého gymnázia, pracujícími ve skupinách na řešení vybraných úloh. Data byla získána prostřednictvím participačního pozorování, terénních zápisků experimentátorky a externího pozorovatele, žákovských prací a zejména videozáznamů. Stručně je popsán způsob analýzy dat prostř̌ednictvím technik založených na zakotvené teorii. Mezi výsledky experimentu patří charakteristika dvou kategorií, a to (relativně) individuální a společné konstrukce poznatků, včetně jejich dimenzí. Jsou podány konkrétní př́klady těchto konstrukcí. Závěrem jsou shrnuty prŕnosy, ale i omezení předloženého výzkumu a nastíněny možné další otázky zkoumání.
\end{abstract}

Klíčová slova: konstrukce matematických poznatků, individuální konstrukce, společná konstrukce, teorie generických modelů, Pythagorova věta, skupinová práce.

\section{Pupils' construction of knowledge in mathematics}

\begin{abstract}
The article concerns the question of the construction of mathematical knowledge by pupils, namely the mechanism of individual and shared construction of knowledge on the example of re-discovery of Pythagoras' theorem within square grid paper. The theoretical background of work consists of the theory of generic models and constructivist approaches to the teaching of mathematics. A study was carried out of pupils of an 8-year secondary grammar school, working in groups and solving carefully chosen problems. The data were gathered through participation observation, field notes of the researcher and external observer, pupils' works and mainly videorecordings. The analysis of data via techniques based on grounded theory is briefly described. The results of the experiment include the characterisation of categories of (relatively) individual and shared constructions of knowledge, including their dimensions. Concrete examples of these constructions are given. The merits and limits of the presented study are summarised and possible questions of further research outlined.
\end{abstract}

Key words: construction of mathematical knowledge, individual construction, shared construction, theory of generic models, Pythagoras' theorem, group work. 


\section{1 ÚvOD}

Studie popisovaná $\mathrm{v}$ tomto článku je součástí širšího výzkumu prezentovaného v rámci dizertační práce druhé z autorek, která se zabývala procesem konstrukce matematických poznatků ${ }^{1}$ žáky (Ulrychová, 2011). Výsledky řady výzkumů v didaktice matematiky ukázaly, že na konstrukci poznatků je třeba nahlížet jako na sociální proces, tedy že nestačí popisovat, jak si budují poznatky jednotlivci, ale že je třeba zkoumat vzájemné interakce mezi žáky, at̉ už v prostředí školní výuky, nebo klinickými experimenty.

Protože druhá z autorek pracuje jako učitelka matematiky na osmiletém gymnáziu, začali jsme náš výzkum nejdříve pomocí akčního výzkumu, a sice jeho kooperativní varianty, kdy jde o spolupráci učitele z praxe a výzkumníka. Např. J. Průcha, E. Walterová a J. Mareš (1998, s. 19) jej vymezují jako „druh pedagogického výzkumu, jehož účelem je přímo ovlivňovat či zlepšovat určitou část vzdělávací praxe. Akční výzkum zahrnuje intervenční strategie, navrhuje určitá doporučení a pokouší se je realizovat, průběžně sleduje efekty změn a vyvozuje z nich další postup. "Akční výzkum je také možné popsat jako systematickou reflexi profesních situací, která je prováděna učiteli, s cílem jejich dalšího rozvoje (Janík, 2004). Učitel se účastní sledovaného jevu a tento jev se současně stává předmětem výzkumu. Odborníci diskutují, do jaké míry je akční výzkum (zejména ten individuální) „skutečný“ výzkum, který přispívá k rozvoji daného oboru. Např. Ch. Breen (2003) staví individuální akční výzkum na úroveň výzkumu akademického - dochází tedy k závěru, že výzkum učitele výzkumníka odpovídá legitimní formě výzkumu. Názory na tuto problematiku se však různí a vždy je třeba vzít v úvahu závěry konkrétního výzkumu a posoudit jejich širší platnost.

Po provedení několika výukových experimentů na téma Pythagorova věta jsme došli k závěru, že vzhledem k povaze zkoumané problematiky je vhodnější provést klinický experiment. Výukové experimenty provedené v rámci akčního výzkumu nepřinesly dostatečná data, aby je bylo možné analyzovat - kvůli autenticitě výukové situace nebyly pořízeny videozáznamy, nebyl přítomen externí pozorovatel, učitelka se musela soustředit na výukový cíl a na své reakce na podněty žáků, a nemohla tedy věnovat dostatečnou pozornost terénním zápiskům, nestíhala zapisovat výroky žáků apod. Rozhodli jsme se tedy, že je třeba pracovat s menším počtem dětí, získávat data co nejvíce způsoby včetně videozáznamů a potlačit výukové cíle ve prospěch výzkumných. Teprve takový experiment přinesl data, která se dala hluboce analyzovat z hlediska zkoumané otázky. Právě provedený klinický experiment je jádrem článku.

Problematika konstrukce matematických poznatků úzce souvisí s otázkou, jak probíhá poznávací proces v matematice, a s konstruktivistickými př́ístupy k výuce matematiky. Oběma otázkám se věnuje následující oddíl. Mezi teoriemi popisujícími poznávací proces v matematice jsme vybrali teorii generických modelů, protože se jedná o teorii v českém prostředí nejrozšriřenější a podle našeho názoru dobře popisující proces konstrukce poznatků.

\footnotetext{
${ }^{1}$ Zde je na místě terminologická poznámka. Teorie didaktických situací (Brousseau, 1997; Chopin, Novotná, 2011) rozlišuje mezi poznatkem a vědomostí. Stručně řečeno, učitel učí vědomosti, ale poznatky si musí žák zkonstruovat sám pomocí didaktické situace, kterou řeší. V tomto článku však toto rozlišení nepoužíváme, a pokud mluvíme o konstrukci poznatků, myslíme tím, že si žák konstruuje poznatek s porozuměním.
} 


\section{TEORETICKÉ POZADí VÝZKUMU}

V souladu s M. Hejným a F. Kuřinou (2001, s. 103, 111) chápeme proces učení jako „proces konstruování poznatkových struktur u jednotlivých žáků“. Tedy ne hotové matematické struktury, ale jejich hledání je základním rysem vyučování matematice. Podle M. Hejného (2004, s. 27-29) je proces zrození a budování nového matematického poznatku rozčleněn do čtyř hladin a dvou hladinových přechodi̊ (zdvihů), které jsou jádrem poznávacího procesu: ${ }^{2}$ (1) hladina motivace, (2) hladina izolovaných modelů, (3) zobecnění, (4) hladina generických modelů, ${ }^{3}$ (5) abstrakční zdvih, (6) hladina krystalizace (strukturalizace), hladina automatizace.

Hladina motivace je hybným momentem celého poznávacího procesu. M. Hejný a F. Kuřina (2001, s. 105) chápou motivaci jako souhrn podnětů, důvodi̊ k určitému jednání. Klíčovým motivem je rozpor mezi „nevím“ a „chtěl bych vědět“. M. Hejný rozlišuje dva typy motivace - tradiční a konstruktivistickou. Pomocí tradiční motivace zaměřujeme pozornost žáků na jistý jev. Nastíníme např. praktický problém, který je řešitelný tím, co se budeme učit, ale který sám ke zmíněnému novému poznatku žádným způsobem nevede. Konstruktivistická motivace je podle M. Hejného charakterizována dvěma parametry: (1) ve vědomí žáka vyvolává tenzi investigativní zvídavosti, (2) poukazuje na cestu k izolovaným modelům. Investigativní zvídavost je aktivní, nečeká na učitelovo řešení úlohy (dokonce se mu vyhýbá a někdy je odmítá), ale vede žáka k samostatnému řešení.

Hladina izolovaných modeli̊ v sobě zahrnuje postupné nabývání zkušeností s konkrétními př́pady budoucího poznání. Izolované modely jsou reprezentanty obecného pojmu (např. izolovanými modely čísla 3 jsou 3 jablka, 3 knoflíky, ... ). Různorodost a množství těchto modelů podporuje pevnější výsledné poznání žáka. Izolované modely začnou na sebe nejprve vzájemně poukazovat, různě se seskupovat a organizovat, až dojde $\mathrm{k}$ jejich strukturaci, $\mathrm{k}$ hlubšímu a operativnějšímu vhledu do dosavadního poznání. Jedná se často jen o krátký časový interval, v němž ve vědomí vznikne generický model (Hejný, 2004, s. 28). Proces objevování a objevení generického modelu je zobecněním. Generický model je prototypem bud' všech, nebo jisté skupiny izolovaných modelů, může zastupovat kterýkoli z izolovaných modelů této skupiny a působí ve skupině jako její organizační agent. Např́klad použití prstů, popř. počitadla, je generickým modelem pro počítání předmětů.

Abstrakční zdvih podněcuje zrod abstraktnîho poznání. Soubor izolovaných a generických modeli̊ je restrukturován, a žák tak získá nový vhled, který má abstraktnější charakter (Hejný, 2004, s. 28). Abstraktní znalost je tedy zbavena své závislosti na světě věcí a je často vyjádřena symbolickým záznamem, který novou strukturu reprezentuje - např. pomocí matematické symboliky.

Znalost, která není opřena o žádný izolovaný model, o žádnou konkrétní představu, je obvykle silně formální. Žák ji ve vědomí uchovává jako pamětový údaj bez účinného propojení na jiné poznatky a bez schopnosti použít ji v jiných než standardních situacích. V takovém př́ípadě spočívá reedukace v dobudování chybějících představ (tedy izolovaných a generických modelo̊).

Proces konstrukce poznatků je již ze své podstaty neukončený. Otázkou je, kdy je možno považovat poznatek za „zkonstruovaný“. Můžeme např. očekávat, že se tak stane ve chvíli, kdy je připraven na takové úrovni, aby ho žák dokázal dobře

\footnotetext{
${ }^{2}$ Hranice mezi těmito hladinami jsou neostré, jednotlivé hladiny se překrývají. Hladina motivace je aktivní v průběhu celého procesu.

${ }^{3}$ Ve starší literatuře používá M. Hejný pojmy separované a univerzální modely. V novější literatuře se objevují pojmy izolované a generické modely.
} 
využívat (tedy i v nestandardních úlohách). K tomu je potřeba tento poznatek konsolidovat (Hershkowitz, Schwarz, Dreyfus, 2001); v jazyce teorie generických modelů musí tento poznatek krystalizovat. Na hladině krystalizace se nové poznání propojuje s předchozími vědomostmi - nejprve na úrovni modelů, potom na úrovni abstraktního poznání. Jde tedy o rozšiřování poznatku. Objevují se další izolované a generické modely a dochází $\mathrm{k}$ propojení nového poznatku s poznatky předchozími i novými. Jedná se obvykle o dlouhodobý proces (Hejný, 2004, s. 29). ${ }^{4}$ Protože jsme v našich experimentech nesledovali vývoj konstrukce poznatku z dlouhodobého hlediska, budeme zde konstrukcí poznatku myslet okamžik, kdy se poznatek poprvé objeví v mysli žáka. ${ }^{5}$

Teorie generických modelů popisuje proces konstrukce poznatků z hlediska kognitivního vývoje žáka. Učení však není individuálním procesem, k němuž dochází u jedince, ale je chápáno jako proces aktivní konstrukce poznatků žákem v interaktivním učebním prostředí (např. Steinbring, 2005, s. 62), kde do interakce vstupují žáci, učitel, učební látka a další proměnné. To jsme měli při realizaci našich experimentů na paměti.

Z mnoha domácích i zahraničních výzkumů víme, že účinnost výuky narůstá, když respektuje mechanizmus poznávacího procesu. Tomu dobře vyhovuje konstruktivisticky pojaté vyučování matematice, pro které je podle M. Hejného a F. Kuřiny (2001, s. 162) charakteristické „aktivní vytváření části matematiky v duševním světě dítěte". Podle konstruktivistického přesvědčení je tedy k nabytí poznání nutná intelektuální aktivita žáka. Důležitou roli hraje žákova vnitřní motivace; úlohou učitele je tuto motivaci navozovat. Protože se výuka odehrává v kolektivu, působící faktory jsou jak sociální, tak psychologické i kognitivní. „Součinností všech faktorů je ve třídě vytvářeno jisté prostředí a cílem konstruktivisticky zaměřeného učitele je, aby toto prostředí bylo podnětné, aby povzbuzovalo zvídavost žáků, aby jim dopřálo pocit radosti z nového poznání i pocit sociální seberealizace“ (Stehlíková, 2004b, s. $16-17)$.

Ve výuce hrají klíčovou roli použité úlohy. Některé úlohy jsou pro podnětné vyučování vhodnější, jiné méně vhodné. Za úlohu vhodnou pro podnětné vyučování považuje např. D. Jirotková (2010, s. 231) takovou úlohu, která (1) je pro řešitele nestandardní - musí vyvinout intelektuální úsilí, aby ji vyřešil, (2) je k řešiteli vstř́ícná - je schopen úlohu uchopit a má jistou představu, co s ní má dělat, (3) má nastavitelnou obtížnost, kterou si př́ípadně může volit řešitel sám. Podnětným prostředím podle N. Stehlíkové (2007, s. 20) může být problém, projekt nebo série úloh, které „mají žáka motivovat k vlastnímu poznávání matematiky, a jejich řešení má vést ke konstrukci nového matematického poznání. Může se jednat o problém z praxe, ale i o problém čistě matematický. K jeho řešení využívá žák své dosavadní poznatky a zkušenosti, ale může též vyhledávat v literatuře, v učebnicích, u kolegů apod."

I když je konstruktivizmus primárně teorií učení, teorií epistemologickou, je její projekce do práce učitele i teorií vyučování. V našem pojetí se zde mluví o podnětném vyučování, které lze popsat souborem charakteristik: motivuje žáky (k vlastnímu objevování, ke spolupráci apod.), klade důraz na aktivitu žáků, povzbuzuje zvídavost žáků, podněcuje jejich tvořivost a vůbec tvůrčí klima, dá možnost žákům použít při řešení úlohy různé strategie, dává žákům možnost vytvořit si dosta-

\footnotetext{
${ }^{4} \mathrm{Na}$ předcházející proces navazuje hladina automatizace, která však nenáleží do poznávacího procesu, protože zde nedochází k novému poznání, ale k nácviku poznaného.

${ }^{5}$ Je jasné, že o tom se pozorovatel dozví jen zprostředkovaně, např. tím, že žák něco řekne, napíše, vyřeší úlohu apod.
} 
tečné množství izolovaných modelů, aby se zamezilo formálnímu poznání, vede žáky k objevování, zdůvodňování a formulaci vlastních myšlenek, k ověřování správnosti, diskuzím, experimentování atd.

\section{Metodologie}

V tomto článku se soustředíme na jednu z výzkumných otázek, uvedenou v (Ulrychová, 2011), a to Jaký je mechanizmus individuální a společné konstrukce poznatků u žáki̊ určitého ročníku na př́kladu re-konstrukce poznatku Pythagorova věta.

Jako výzkumná metoda byl použit výukový experiment. Tento experiment výzkumník organizuje s určitým záměrem - chce něco ověřit, zjistit, podrobněji popsat apod. Snaží se tedy kontrolovat co nejvíce proměnných, což bývá v pedagogickém výzkumu problém. V našem případě bylo předem určeno: místo, čas, délka trvání a cílová skupina, cíl, téma rozpracované do úloh, forma práce, míra pomoci žákům a způsob sběru dat.

Experiment byl proveden se žáky kvarty osmiletého studia (odpovídající 9. ročníku základní školy) v červnu 2008; druhá z autorek znala žáky z hodin německého jazyka, ale nebyla jejich učitelkou matematiky. Vystupovala tedy pouze v roli experimentátorky. Experiment byl koncipován jako klinický, účastnil se ho menší počet žáků, výukové cíle byly potlačeny ve prospěch výzkumných a jako zdroj dat bylo zvoleno participační pozorování, terénní zápisky, žákovské práce a diskuze se žáky ( $\mathrm{v}$ průběhu hodiny) a zejména videonahrávka celého průběhu experimentu a př́ítomnost externího pozorovatele. Byly použity čtyři videokamery, aby bylo možné nahrát práci všech skupin.

Jako téma byla zvolena Pythagorova věta objevovaná metodou postupného uvolňování konstant (viz také Jirotková, 2010). Tato věta byla žákům známa již ze sekundy, kde jim byla předložena tradičním instruktivním způsobem. Sekundárním cílem experimentu bylo tedy zjistit, do jaké míry budou žáci schopni propojit si již známý poznatek, s nímž se setkali v jednom kontextu, na poznatek v rámci kontextu čtverečkovaného papíru. Žáci v prostředí čtverečkovaného papíru v hodinách matematiky běžně nepracovali.

Vzhledem k výzkumné otázce byla zvolena skupinová forma práce. Žáci měli řešit dané úlohy zformulované na jednotlivých pracovních listech, které jim experimentátorka plánovala dávat postupně, vždy po vyřešení předcházející úlohy, a nahlas mezi sebou úlohy řešit, zdůvodňovat svá řešení a argumentovat. Experimentu se účastnilo celkem 13 žáko̊ (3 chlapci a 10 dívek) rozdělených do 4 skupin (1 skupina po čtyřech a 3 skupiny po třech žácích). Tato forma práce vyžadovala určitou míru samostatnosti, na kterou však žáci nebyli zvyklí, protože v jejich hodinách matematiky značně převládala frontální forma výuky. Toho si byla experimentátorka vědoma a očekávala možné problémy s tím, že žáci budou vyžadovat větší míru pomoci.

Byly připraveny pracovní listy, aby mohli žáci pracovat ve skupinách co nejsamostatněji a s co nejmenší intervencí vyučující. Ulohy byly připraveny tak, aby vedly ke konstruktivistické motivaci, tedy měly ukázat cestu k izolovaným modelům Pythagorovy věty.

Nejdřive byla se žáky dohodnuta symbolika: např. čtverec nad úsečkou v úloze 3a je označen jako $\rightarrow \uparrow(1$ krok doprava a 1 krok nahoru). 
Tab. 1

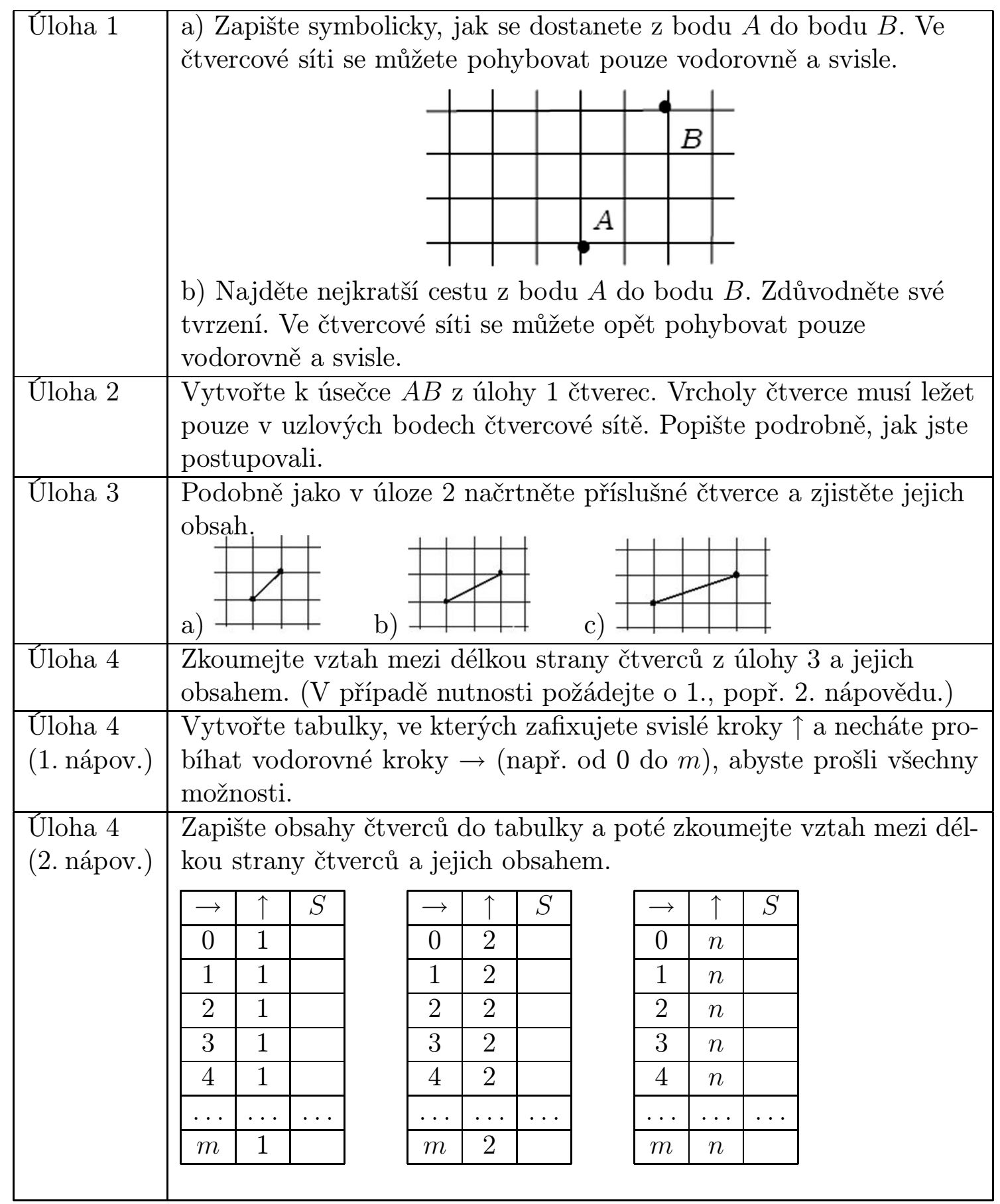

\section{POZNÁMKY K ŘEŠENÍ ÚLOH}

Úloha 1: Tato úloha byla př́ípravná a měla žáky seznámit s prostředním čtverečkovaného papíru a se symbolikou, která se využívá dále. Symbolickým zápisem může být např. šipkový zápis $A \rightarrow \rightarrow \uparrow \uparrow \uparrow B, A \rightarrow \uparrow \uparrow \uparrow \rightarrow B$ apod. Experimentátorka zpřesnila zadání úlohy v průběhu experimentu vysvětlením, že „symbolicky znamená např. pomocí znaků“, a u části b) vedla žáky k nalezení více cest.

Úloha 2: Pokud to bylo nutné, experimentátorka upřesnila, že se jedná o čtverec $A B C D$, tedy že úsečka $A B$ je stranou hledaného čtverce. Na základě předchozích experimentů jsme očekávali, že se objeví jak strategie konstrukce čtverce využívající 
potenciálu čtverečkovaného papíru, tak konstrukce na čistém papíru pomocí rýsovacích pomůcek.

Úloha 3: Očekávali jsme několik typů řešení: a) Metoda rozkladu, kdy je čtverec rozdělen na čtverec a čtyři pravoúhlé trojúhelníky, u nichž už žáci umí nalézt obsah, b) metoda rámování, kdy je čtverec vepsán do nejmenšího možného mřížového čtverce, u něhož žáci umějí najít obsah, a od tohoto obsahu se odečte obsah čtyř pravoúhlých trojúhelníků (viz obr. 2 níže), c) použití vzorců. Podle našich zkušeností je první strategie u žáků tohoto věku častější a pro žáky jednodušší. Zpravidla ji spontánně objeví.

Úloha 4: Čtverec sestrojený nad úsečkou je vlastně čtverec sestrojený nad přeponou pravoúhlého trojúhelníku (viz např. obr. 4 níže). Výsledkem zobecnění údajů v tabulkách je Pythagorova věta a cílem úlohy bylo znovuobjevení této věty. (Úloha je více diskutována níže.)

\section{PRŮBĚH EXPERIMENTU}

Experiment byl proveden ve školní třídě ve dvou po sobě jdoucích vyučovacích hodinách. Po celou dobu byla účastna externí pozorovatelka. Ve třídě byly čtyři videokamery, každá byla namířena na jednu skupinu tak, aby zabírala všechny žáky ve skupině. Žáci s př́tomností kamer souhlasili a během experimentu se zdálo, že nemají s natáčením žádný problém.

Žáci pracovali samostatně na jednotlivých úlohách, experimentátorka obcházela tř́idu a všímala si, jak pracují. O tom si dělala poznámky, stejně jako externí pozorovatelka. Protože se nejednalo o hodinu matematiky a byly přítomny kamery, lze předpokládat, že pro žáky byla tato situace poměrně neobvyklá a nepocitovali ji jako běžnou hodinu matematiky. Na druhou stranu na ně nebyl vyvíjen žádný tlak, co se týče získávání matematických poznatků.

Na začátku hodiny po společném úvodu, kdy experimentátorka žáky požádala, aby se snažili svá řešení co nejpodrobněji popisovat, je vyzvala, aby se rozdělili do čtyř skupin podle svého uvážení. To proběhlo bez problémů. V každé skupině byla zadána první úloha na samostatném listu papíru a žáci začali pracovat. Po vyřešení zadané úlohy se skupiny přihlásily, aby jednotlivě mohly okomentovat své řešení a aby dostaly následující úlohu. Zde začaly vznikat prostoje, protože některé skupiny musely čekat, než experimentátorka vyslechla řešení jiných, a to snižovalo jejich koncentraci na práci a zvyšovalo únavu. Experimentátorka však nechtěla, aby jednotlivé skupiny navzájem poslouchaly svá řešení. Při komunikaci s žáky v jednotlivých skupinách se vždy snažila, aby je co nejméně naváděla a ovlivňovala. Hlavním cílem bylo pochopit jejich řešení, aby mohla následně adekvátně analyzovat jejich práci a proces, jakým si tvoří poznatky.

U úlohy 4 byly připraveny dvě nápovědy pro případ, že by žáci nevěděli, jak pokračovat. První nápověda (viz tab. 1) byla v průběhu experimentu doplněna takto: Existuje mezi danými údaji a obsahem čtverce určitá závislost? Původní nápověda nebyla totiž žákům srozumitelná. Skupina 2 se nápovědě bránila a snažila se úlohy vyřešit bez ní. Ostatní skupiny nápovědu přijaly.

Externí pozorovatelku překvapilo, jak moc byli žáci vstřícní k řešení úloh, ale také vůči sobě. Pracovali dobře, nesnažili se skončit dříve, pracovali navzdory tomu, že nemuseli. V průběhu realizace experimentu však přece jen pozornost trochu poklesla.

Podrobně je práce všech čtyř skupin popsána v disertační práci (Ulrychová, 2011). Zde se - vzhledem k výzkumné otázce - podíváme na to, jak se jednot- 
liví členové skupiny zapojovali do práce, a alespoň rámcově popíšeme, jaké strategie řešení úloh se objevily. Ve skupině 1 se nejvíce do práce zapojovaly Nela ${ }^{6}$ a Anežka, které práci vedly, o trochu méně Klára. Marcela většinou práci dívek jen pozorovala. Ve skupině 2 se do práce př́liš nezapojovala Claudie a spíše se ocitla v roli pozorovatelky. Pro dívky v této skupině bylo typické, že hodně úsilí věnovaly pořádku na stole. Skupina 3 pracovala na úlohách podle odhadu pozorovatelky pouze přibližně jednu třetinu času, jinak se bavili o něčem jiném. Práci skupiny řídila Bára. Ve skupině 4 probíhala práce pouze mezi Davidem a Jakubem; Martin se často bavil s dívkami ze skupiny 3 .

Tabulka 2 stručně popisuje použitý zpo̊sob řešení daných úloh jednotlivými skupinami. Řádky obsahují jednotlivé strategie řešení úloh, u nichž je vždy uvedeno, která skupina či skupiny je využily.

Jak je vidět $\mathrm{z}$ tabulky 2 , žáci vesměs používali Pythagorovu větu spontánně již při výpočtu délky strany čtverce, jehož obsah měli počítat. ${ }^{7} \mathrm{~K}$ souvislosti úlohy 4 s Pythagorovou větou dospěly tři skupiny, z nichž dvě to též explicitně vyjádřily.

\section{ANALÝZA EXPERIMENTU}

Pro podrobnou analýzu byla vybrána skupina 1 . Důvodem bylo, že dívky z této skupiny dobře spolupracovaly, byly aktivní, ochotně na kameru popisovaly svá řešení a živě s experimentátorkou o své práci hovořily. Videozáznam jejich práce byl přepsán do protokolu o 39 stranách a podroben analýze z hlediska výzkumné otázky, a to pomocí technik zakotvené teorie. ${ }^{8}$ U skupin 2 až 4 byl na základě videozáznamů pořízen stručnější zápis o jejich práci tak, aby bylo možno popsat „dějové linie“, tedy shrnutí procesu, jak řešily úlohy. Na základě výsledků podrobné analýzy práce skupiny 1 byla pak analyzována i práce skupin 2 až 4 . Vzhledem k omezenému rozsahu článku bude podrobněji ilustrována analýza práce skupiny 1 a následně shrnuty výsledky, k nimž jsme dospěli na základě práce všech čtyř skupin.

$\mathrm{V}$ celém procesu řešení čtyř zadaných úloh byla identifikována konstrukce pěti poznatků: P1 - symbolický zápis, P2 - rovnost nejkratších cest, P3 - postup konstrukce mřižového čtverce, P4 - strategie hledání obsahu mřížového čtverce, P5 tvorba systematického př́stupu. Zde se budeme věnovat zejména poznatku $\mathrm{P} 4$.

\footnotetext{
${ }^{6}$ Byla použita jiná jména.

${ }^{7}$ Vybavila se jim tedy, když měli hledat délku šikmé mř́ižové úsečky - všimli si zřejmě okamžitě pravoúhlého trojúhelníka, u něhož byla daná úsečka přeponou.

${ }^{8}$ Pojem zakotvená znamená, že závěry, které učiníme na základě analýzy, jsou zakotvené ( „grounded“) v reálných údajích, tzn. nevznikly teoreticky. Jedná se o opak toho, kdy výzkumník formuluje určitou teorii, kterou pak chce potvrdit, nebo vyvrátit experimentem. U metody zakotvené teorie přistupuje výzkumník $\mathrm{k}$ datům bez předchozí teorie, ta teprve postupně vystupuje z analýzy (Strauss, Corbinová, 1999, s. 14, 191). Základem této metody je odhalení a analýza jevů, které umožňují porozumět podstatě zkoumaného problému. Jádrem zakotvené teorie je fáze kódování. Otevřené kódování je proces rozebírání, prozkoumávání, porovnávání, pojmenování (konceptualizace) a kategorizace údajů. Výsledkem tohoto procesu jsou pojmy a kategorie, které jsou základními stavebními kameny teorie. Axiálni kódováni je soubor postupů, pomocí nichž jsou údaje po otevřeném kódování znovu uspořádány novým způsobem, prostřednictvím vytváření spojení mezi kategoriemi. Vzniká struktura kategorií a jejich podkategorií. Kategorie jsou následně podrobněji rozpracovány. Selektivni kódování je proces, kdy se vybere zpravidla jedna centrální kategorie, kolem které je organizován základní analytický příběh. Jako centrální kategorie byla v rámci dvou výukových experimentů, předcházejících experimentu popisovanému v tomto článku. identifikována kategorie Konstrukce matematických poznatků. Podrobněji je celá analýza popsána a ilustrována v (Ulrychová, 2011).
} 
Tab. 2

\begin{tabular}{|c|c|c|c|}
\hline $\begin{array}{l}\text { Úloha } 1- \\
\text { šipkový zápis }\end{array}$ & $\begin{array}{l}\text { Úloha } 2- \\
\text { konstrukce } \\
\text { čtverce nad } \\
\text { úsečkou }\end{array}$ & $\begin{array}{l}\text { Úloha } 3 \text { - obsah } \\
\text { mřižového čtverce }\end{array}$ & $\begin{array}{l}\text { Úloha } 4- \\
\text { odhalení vztahu } \\
\text { pro PV }\end{array}$ \\
\hline $\begin{array}{l}\text { přímo na čtve- } \\
\text { rečkovaném } \\
\text { papíře; viz } \\
\text { obr. } 1 \text { vlevo } \\
\text { (skup. } 2,3 \text { a } 4 \text { ) }\end{array}$ & $\begin{array}{l}\text { pomocí kolmic } \\
\text { a s využitím } \\
\text { potenciálu čtve- } \\
\text { rečkovaného } \\
\text { papíru - „dva } \\
\text { nahoru a jeden } \\
\text { doleva“ apod. } \\
\text { (skup. 1, } 2 \text { a } 3 \text { ) }\end{array}$ & $\begin{array}{l}\text { součet obsahu čtverce } \\
\text { a } 4 \text { trojúhelníků; viz } \\
\text { obr. } 2 ; \text { jednotkou } \\
\text { obsahu je čtverec } \\
0,5 \mathrm{~cm} \times 0,5 \mathrm{~cm}^{*} \\
\text { (skup. } 1 \text { ) }\end{array}$ & $\begin{array}{l}\text { viz popis } \\
\text { v odstavci } 6 \text { a obr. } 8 \\
\text { (skup. } 1)\end{array}$ \\
\hline \multirow[t]{4}{*}{$\begin{array}{l}\text { mimo } \\
\text { čtverečkovaný } \\
\text { papír; viz } \\
\text { obr. } 1 \text { vpravo } \\
\text { (skup. } 1 \text { a 4) }\end{array}$} & $\begin{array}{l}\text { pomocí } \\
\text { pravítka } \\
\text { s ryskou } \\
\text { a nanášení } \\
\text { vzdálenosti } \\
\text { (skup. 2) }\end{array}$ & $\begin{array}{l}\text { jako výše, jen } \\
\text { jednotkou obsahu je } \\
\text { čtverec } 1 \mathrm{~cm} \times 1 \mathrm{~cm} \text {; } \\
\text { viz obr. } 2^{* *} \text { od } \\
\text { skupiny } 2(\text { skup. } 2,4)\end{array}$ & $\begin{array}{l}\text { s pomocí } \\
\text { experimentátorky } \\
\text { nalezen vztah } \\
m^{2}+n^{2}=S, \text { kde } m \\
\text { a } n \text { jsou odvěsny } \\
\text { a } S \text { obsah čtverce } \\
\text { nad přeponou } \\
\text { daného pravoúhlého } \\
\text { trojúhelníka; } \\
\text { skupina } 2 \text { explicitně } \\
\text { neřekla, že se jedná } \\
\text { o Pythagorovu větu }\end{array}$ \\
\hline & $\begin{array}{l}\text { otáčení } \\
\text { obdélníka } 2 \times 1 \\
\text { (skup. } 4- \\
\text { obr. } 3 \text { ) }\end{array}$ & $\begin{array}{l}\text { nalezení délky strany } \\
\text { čtverce pomocí } \\
\text { Pythagorovy věty } \\
\text { a dále využití vzorce } \\
\text { pro obsah čtverce; } \\
\text { jednotkou obsahu je } \\
0,5 \mathrm{~cm} \times 0,5 \mathrm{~cm} \\
(\text { skup. } 1,2,3 \text { a } 4)\end{array}$ & $\begin{array}{l}\text { na př́ikladu } \\
\text { konkrétního } \\
\text { trojúhelníku (obr. 4) } \\
\text { vysvětleno, že se } \\
\text { jedná o Pythagorovu } \\
\text { větu a že to půjde } \\
\text { vždy (skup. 3) }\end{array}$ \\
\hline & & $\begin{array}{l}\text { nalezení délky strany } \\
\text { čtverce pomocí } \\
\text { Pythagorovy věty } \\
\text { a dále využití vzorce } \\
\text { pro obsah čtverce; } \\
\text { jednotkou obsahu je } \\
1 \mathrm{~cm} \times 1 \mathrm{~cm}(\text { skup. } 4)\end{array}$ & \\
\hline & & $\begin{array}{l}\text { změření délky strany } \\
\text { čtverce pravítkem } \\
\text { a pak využití vzorce } \\
\text { pro obsah čtverce } \\
\text { (skup. } 1 \text { a } 4 \text { ) }\end{array}$ & \\
\hline
\end{tabular}

* Skutečná délka strany čtvercové sítě.

** Je zajímavé, že se zde objevuje i rámování čtverce, jehož obsah se zjištuje, do většího čtverce, ovšem žákyně tuto strategii vůbec nepopisovaly. 


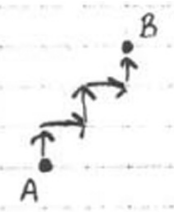

$$
1 \times \uparrow, 1 x \rightarrow, 1 \times \uparrow, 1 x \rightarrow 1 \times \uparrow
$$

Obr. 1

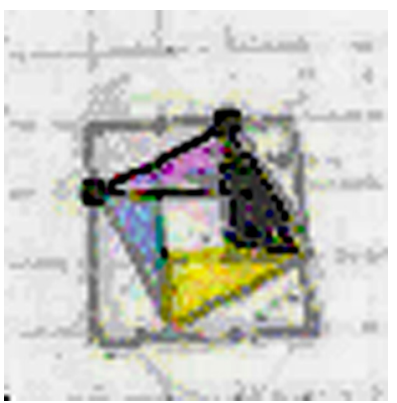

Obr. 2

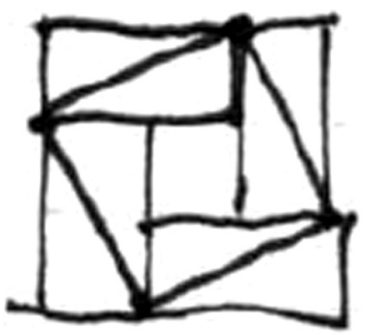

Obr. 3

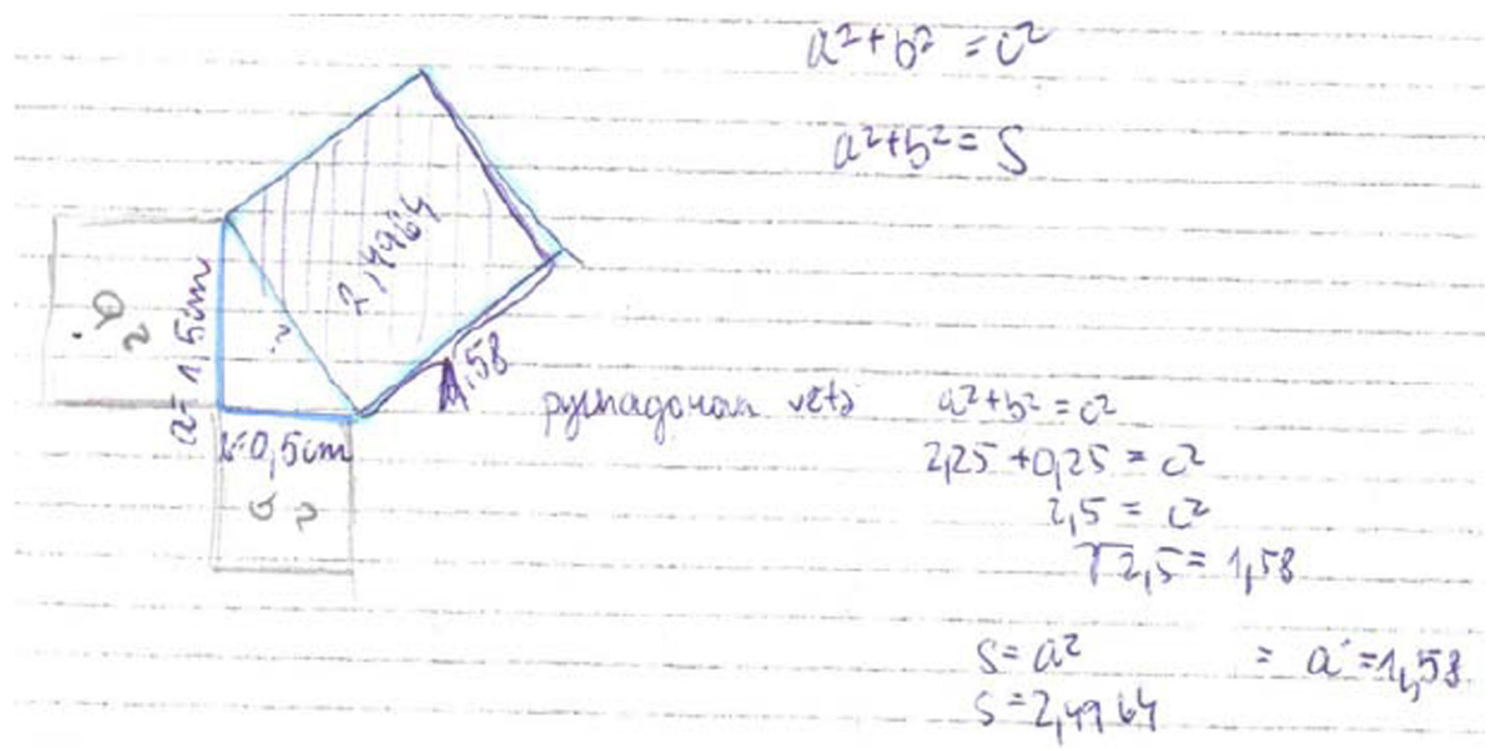

Obr. 4

Podrobná analýza práce skupiny 1 byla provedena na třech úrovních:

1. Výsledek, $\mathrm{k}$ němuž se skupina $\mathrm{v}$ konstrukcích jednotlivých poznatků dobrala (řšsitelské strategie).

2. Cesta, jakou to dívky jako skupina udělaly.

3. Celý proces z hlediska jednotlivých členek skupiny.

Výsledek analýzy byl zaznamenán do tabulky, kterou je možné číst po řádcích představujících jednotlivé úrovně analýzy i sloupcích představujících jednotlivé poznatky, $\mathrm{k}$ nimž se měly dívky řešením úloh dobrat ( $v$ tab. 3 je ukázán př́íklad konstrukce poznatku P4 Strategie hledání obsahu čtverce u úlohy 3a). Ve druhém řádku získáme představu o tom, jaký způsob řešení dívky nakonec společně vytvořily. Ve třetím se dočteme o procesu, jakým tento způsob řešení vznikal. V dalších čtyřech řádcích je možné projít celým procesem řešení úlohy z pohledu každé dívky ze skupiny (pro stručnost používáme v tab. 3 jen jejich iniciály). Do těchto řádků jsou vybrány pozorovatelné projevy dívek ukazující na to, jak asi uvažovaly. Pokud čteme tabulku po sloupcích, pak se směrem dolů zvyšuje podrobnost celého popisu konstrukce poznatku. 
Tab. 3

\begin{tabular}{|c|c|}
\hline $\begin{array}{l}\text { Konstruované } \\
\text { poznatky }\end{array}$ & Strategie hledání obsahu čtverce u úlohy $3 a\left(P_{4}\right)$ \\
\hline $\begin{array}{l}\text { Úroveř } 1 \\
\text { Výsledek práce } \\
\text { celé skupiny }\end{array}$ & $\begin{array}{l}\text { Rozřezání čtverce na jednotlivé části (v tomto případě } \\
4 \text { trojúhelníky) a jejich přeskládání, tedy složení dvou } \\
\text { jednotkových čtverců ze čtyř shodných trojúhelníků (viz obr. } 6 \\
\text { v odstavci } 6 \text { ). }\end{array}$ \\
\hline $\begin{array}{l}\text { Uroveř 2 } \\
\text { Proces } \\
\text { konstrukce } \\
\text { poznatku celé } \\
\text { skupiny }\end{array}$ & $\begin{array}{l}\text { A. začne přemýšlet s N. nad délkou strany čtverce } \rightarrow \uparrow, \\
\text { K. napadne řešení, že obsah čtverce jsou dva čtverečky, tuto } \\
\text { myšlenku postřehne N.; A. a N. nedojdou zatím k závěru (drží } \\
\left.\text { se své myšlenky, že jde o „a krát } a^{\prime \prime}\right) \text {. N. zopakuje přesvědčivě } \\
\text { řešení K., že obsah čtverce jsou dva čtverečky, a rozvíjí ho: } \\
\text { "Protože tady jsou takhle ty trojúhelníčky.“ K. to komentuje } \\
\text { „Jo, já už to vidím.“, jakoby to až ted’ pochopila. A. vnímá } \\
\text { návrh řešení N. a ujme se dále řešení úlohy, N. jí přizvukuje } \\
\text { a snaží se A. doplňovat. Na závěr A. a K. dopočítají konkrétní } \\
\text { výpočet obsahu. }\end{array}$ \\
\hline $\begin{array}{l}\text { Uroveř } 3 \\
\text { Proces } \\
\text { konstrukce } \\
\text { Nely }\end{array}$ & $\begin{array}{l}\text { N. přemýšlí s A. nad délkou strany čtverce } \rightarrow \uparrow \text {, ale zároveň } \\
\text { vnímá i poznámku K. o obsahu čtverce a následně pak zopakuje } \\
\text { řešení Kláry a rozvine ho: „No jsou to dva čtverečky, že jo, } \\
\text { protože tady jsou takhle ty trojúhelníčky." N. byla zřejmě } \\
\text { inspirována řešením K., protože když K. své řešení vyslovila, } \\
\text { nikdo na K. nereagoval, jen N. se na ni udiveně podívala. } \\
\text { Potom se ujme s A. dále řešení úlohy, N. ji spíše doplňuje. }\end{array}$ \\
\hline $\begin{array}{l}\text { Proces } \\
\text { konstrukce } \\
\text { Anežky }\end{array}$ & $\begin{array}{l}\text { A. nejprve přemýšlí nad délkou strany čtverce } \rightarrow \uparrow \text {. Poté, když } \\
\text { nedojde k žádnému závěru, začne vnímat návrh řešení N., že } \\
\text { obsah čtverce jsou dva čtverečky, a ujme se dále řešení úlohy: } \\
\text { „Jo, tak dobře. Tak } a \text { krát } a \text { krát } 2 . “, ~ „ a \text { krát } a \text { je jeden } \\
\text { čtvereček, krát } 2 \text { je druhý čtvereček.“. To převzala od N. a dále } \\
\text { se ujala řešení úlohy. Na závěr dopočitají A. a K. konkrétní } \\
\text { výpočet obsahu. }\end{array}$ \\
\hline $\begin{array}{l}\text { Proces } \\
\text { konstrukce } \\
\text { Kláry }\end{array}$ & $\begin{array}{l}\text { „Obsah jsou dva čtverečky,“ prohlásí celkem jistě na začátku } \\
\text { a pak se již hned připojí k diskuzi A. a N. nad délkou strany } \\
\text { čtverce } \rightarrow \uparrow \text {. Potom již přihlíží k práci A. a N. Na závěr } \\
\text { dopočítají A. a K. konkrétní hodnotu obsahu. }\end{array}$ \\
\hline $\begin{array}{l}\text { Proces } \\
\text { konstrukce } \\
\text { Marcely }\end{array}$ & Pokud lze soudit, pouze přihlíží. \\
\hline
\end{tabular}

Na základě rozepsání konstrukce jednotlivých poznatků byly následně identifikovány př́ipady, kdy byly tyto poznatky pravděpodobně vytvořeny ve spolupráci a kdy víceméně individuálně, a současně byla pozornost věnována tomu, co k těmto konstrukcím vedlo. Tato analýza byla následně zopakována u popisu práce ostatních tř́ skupin, kdy bylo opět využito videozáznamu a žákovských prací. Některé výsledky shrnuje následující oddíl.

\section{VÝSLEDKY EXPERIMENTU}

Nyní se podíváme na výsledky analýzy u všech čtyř skupin z hlediska výzkumné otázky. Celý proces konstrukce poznatků můžeme vizualizovat schématem na obr. 5 . 
Schéma ukazuje centrální kategorii Konstrukce poznatků a její dvě podkategorie. Ty jsou charakterizovány svými dimenzemi.

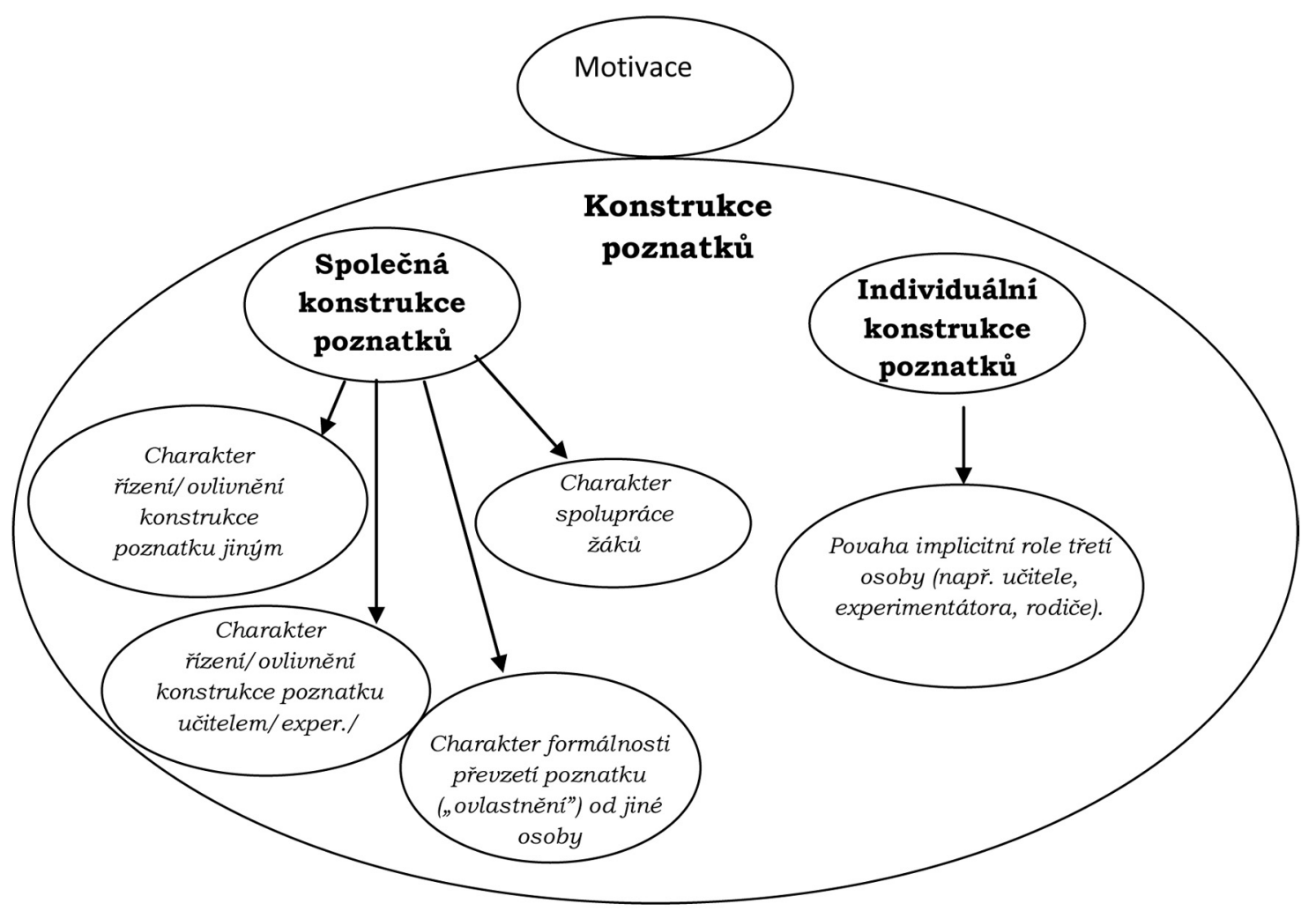

Obr. 5

Jak již bylo řečeno, důležitou součástí poznávacího procesu je motivace. V našem případě byli žáci motivováni neobvyklou situací (experimentátorka jim vysvětlila, že jsou účastníky experimentu) i zadanými úlohami a samozřejmě tím, že se jim dařilo nacházet řešení úloh. Ty byly pro ně sice neobvyklé, ale současně byly gradovány tak, že všichni zúčastnění žáci dokázali s jejich řešením začít. Získaná data nám však neumožňují analyzovat, proč byli někteří žáci (např. ve skupině 1) motivováni více než jiní (např. ve skupině 3), tedy proč bylo jejich pracovní nasazení různé. To by bylo možné snad jen za předpokladu, že by byly provedeny rozhovory s jednotlivými žáky a získána další data napřs. od jejich učitele matematiky (třeba jaký mají vztah $\mathrm{k}$ matematice, jak si v matematice věří apod.).

\subsection{INDIVIDUÁLNÍ KONSTRUKCE POZNATKU}

Při individuální (samostatné) konstrukci si žák buduje poznatek sám, bez očividného podnětu ostatních žáků. Role učitele je v tomto procesu spíše implicitní, tedy daná výběrem úloh, které žák řeší. Jinak žáka učitel nijak neřídí. Je nutné si však uvědomit, že to lze tvrdit jen do té míry, do které jsme to schopni z vnějších projevů žáka posoudit; proto by bylo možná na místě mluvit o konstrukci relativně individuální.

U skupiny 1 bylo identifikováno několik možných individuálních konstrukcí poznatků. Např. u poznatku $\mathrm{P} 4$, kdy zřejmě došlo k individuální konstrukci výpočtu délky strany mřížového čtverce pomocí Pythagorovy věty u Nely a také u Anežky. Nela si vzala pracovní list s úlohami 3a) a 3b), Anežka pracovní list s úlohou 3c), a obě začaly samostatně řešit př́íslušnou úlohu. Nela se po chvilce řešení zeptala: „Strana $a$ se rovná straně $b$, že jo?“ Potřebovala ujištění, nikdo jí však neodpověděl. 
Svým výrokem zřejmě myslela, že se jedná o rovnoramenný trojúhelník, tedy délky dvou stran trojúhelníka se rovnají. Následně napsala $a^{2}+a^{2}=b^{2}$ (viz obr. 6), kde však písmena $a$ a $b$ vystupují v jiné roli (jedno označuje rameno a jedno přeponu). Tento rozpor nikdo nekomentoval. Nela vypracovala celou úlohu sama. Anežka zároveň napsala v úloze $3 \mathrm{c}$ ): $c^{2}=a^{2}+b^{2}$; Nela a Anežka od sebe neopisovaly. Anežka a Klára sice spolupracovaly, ale Anežka se ujala vedení práce. Ke konci Klára Anežku trochu znejistila, že to takto nemůže vypočítat. Tak Anežka odložila list s úlohou 3c) stranou a začala řešit úlohu 3b): „Tady to půjde.“ Anežka zde opět navrhla způsob řešení pomocí Pythagorovy věty.

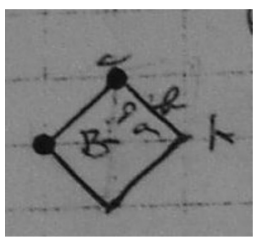

Obr. 6

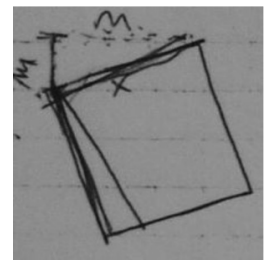

Obr. 7

Dalším př́íkladem individuální konstrukce poznatku je konstrukce poznatku P5 u úlohy 4. Nela pracovala sama, snažila se najít nějakou závislost z úlohy 3 a také se snažila zpřehlednit jednotlivé př́́pady. To ji však k řešení nedovedlo. Nepomohla ani první nápověda, teprve až přeformulování zadání úlohy experimentátorkou (u Nely tedy patrně došlo k individuální konstrukci poznatku s vyšší mírou řízenosti). Nela se dala do psaní a popsala sama postup řešení: „Když je čtverec položen úhlopřričně a já se chci dostat z bodu $A$ do bodu $B$, vždycky jdu nějakou vzdálenost nahoru a určitou vzdálenost doprava. Tím se mi vytvoří pravoúhlý trojúhelník. Přepona toho trojúhelníku je strana čtverce." Nela si dále určila jednotku, což je možno považovat za individuální konstrukci poznatku Určení jednotky v původní individuální konstrukci poznatku Hledání závislosti.

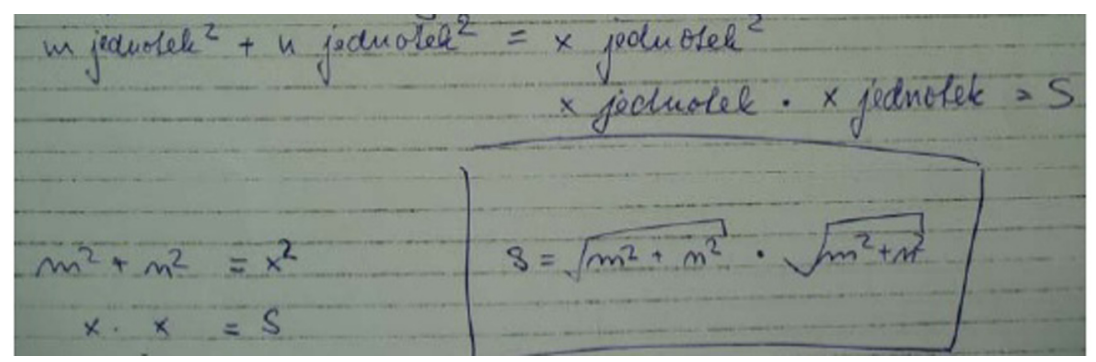

Obr. 8

Nela dále pokračovala $\mathrm{v}$ řešení úlohy - nakreslila úhlopř́ičně mřížový čtverec $\rightarrow \rightarrow \rightarrow \uparrow$ (viz obr. 7). Snažila se tedy uchopit úlohu obecně, bez ohledu na délku strany čtverce. Experimentátorka se zeptala: „Jak vypočítáte obsah toho čtverce, když neznáte délku strany?" Nela popsala postup pomocí dokreslení pravoúhlého trojúhelníku o stranách $m$ a $n$ ke straně čtverce a pomocí odkazu na předchozí konkrétní případ zapsala v podstatě obecné řešení úlohy. To následně popsala i symbolicky jako $S=\sqrt{m^{2}+n^{2}} \cdot \sqrt{m^{2}+n^{2}}$ (viz obr. 8). Můžeme tedy říci, že u Nely došlo k individuální konstrukci poznatku P5 zobecněním konkrétních př́ípadů, i když toto zobecnění nebylo uděláno pomocí tabulky. Figura na obr. 7 je pro ni generickým modelem situace.

U Aleny ze skupiny 2 bylo možno vysledovat individuální konstrukci poznatku $\mathrm{s}$ vyšší mírou řízenosti učitelem u řešení úlohy 4. Dívky neporozuměly přesně za- 
dání, nápovědu dostat nechtěly, a tak se jim experimentátorka pokusila přeformulovat zadání úlohy. Chtěla, aby se zamyslely nad tím, jakým způsobem mưžeme charakterizovat stranu čtverce, který si dívky nakreslily v úloze 4. Dívky nejdřive nechápaly, co myslí. Experimentátorka připomněla dívkám úlohu 3 a Alena určila, že vždycky jde o několik čtverečků nahoru a pak doprava. Experimentátorku zajímalo, jestli i v tomto případě nelze získat danou stranu obdobně. Alena dokreslila k horní straně čtverce $5 \times 5$ pravoúhlý trojúhelník (viz obr. 9). Poté s pomocí experimentátorky zobecnila délky odvěsen $m$ a $n$ pro obecný př́pad, dokreslila nad obě odvěsny př́śslušné čtverce a určila, že $m^{2}+n^{2}$ je rovno obsahu čtverce nad přeponou. Tento obsah označila $S$. Figura na obr. 9 je pro dívky generickým modelem.

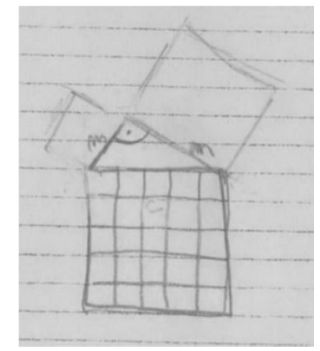

Obr. 9

\subsection{SPOLEČNÁ KONSTRUKCE POZNATKU}

Společná konstrukce poznatku je taková konstrukce, na níž se podílí více než jeden žák. Poznatek již není „individuálním konstruktem jednotlivce, ale stává se majetkem celé skupiny" (Stehlíková, 2004a, s. 288), ovšem jen potud, pokud se poznatek v poznatkové struktuře žáka neuloží jako formální, pokud si ho žák „ovlastní" a pokud se objeví propojení na další poznatky. Charakter tohoto ovlastnění, resp. charakter formálnosti přijetí poznatku, který navrhl někdo jiný (např. jiný žák), je pak důležitou dimenzí kategorie společné konstrukce poznatku.

Nejen v popsaném experimentu, ale i v ostatních (viz Ulrychová, 2011) se jasně ukázalo, že proces společné konstrukce poznatku není lineární, kdy žák A ujde kousek cesty, pak se na to napojí žák B svým kouskem a pokračuje žák $\mathrm{C}$ atd., ale že se spíše jedná o bludiště cest, které jednotliví žáci různě odhalují, porovnávají, zkracují, až nakonec dojdou k nějakému řešení (viz např. proces konstrukce poznatku $\mathrm{P} 4$ v tab. 3 a schéma na obr. 10). Proces společné konstrukce poznatku je permanentní komunikace zúčastněných žáků. Každý z nich pracuje jak na úrovni individuální, tak na úrovni komunikační. Formuluje vlastní poznatky, názory, domněnky a otázky, interpretuje (tj. do vlastních myšlenek vkládá) podněty od spolužáků a reaguje na ně (tj. formuluje mentální amalgám, který se vytváří propojením vlastních i přijatých myšlenek). Řešení navržené nějakým žákem pak může být např. vylepšeno úplně jiným žákem (např. ve zmíněné konstrukci poznatku P4 dovedly k cíli Klárou navržené řešení Nela a Anežka).

Př́kladem společné konstrukce poznatků je konstrukce poznatku P4 popsaná v tab. 3. Objevuje se zajímavá otázka, zda dokážeme tuto společnou konstrukci nějak schematizovat. O takové schéma jsme se pro tuto konkrétní konstrukci pokusili (viz obr. 10). Je v něm naznačeno, jakým zpo̊sobem se dívky ${ }^{9}$ navzájem ovlivňovaly, co vedlo k další části procesu konstrukce apod. Šipky ukazují, kde asi došlo

\footnotetext{
${ }^{9}$ Marcela pouze přihlíží řešení dívek.
} 


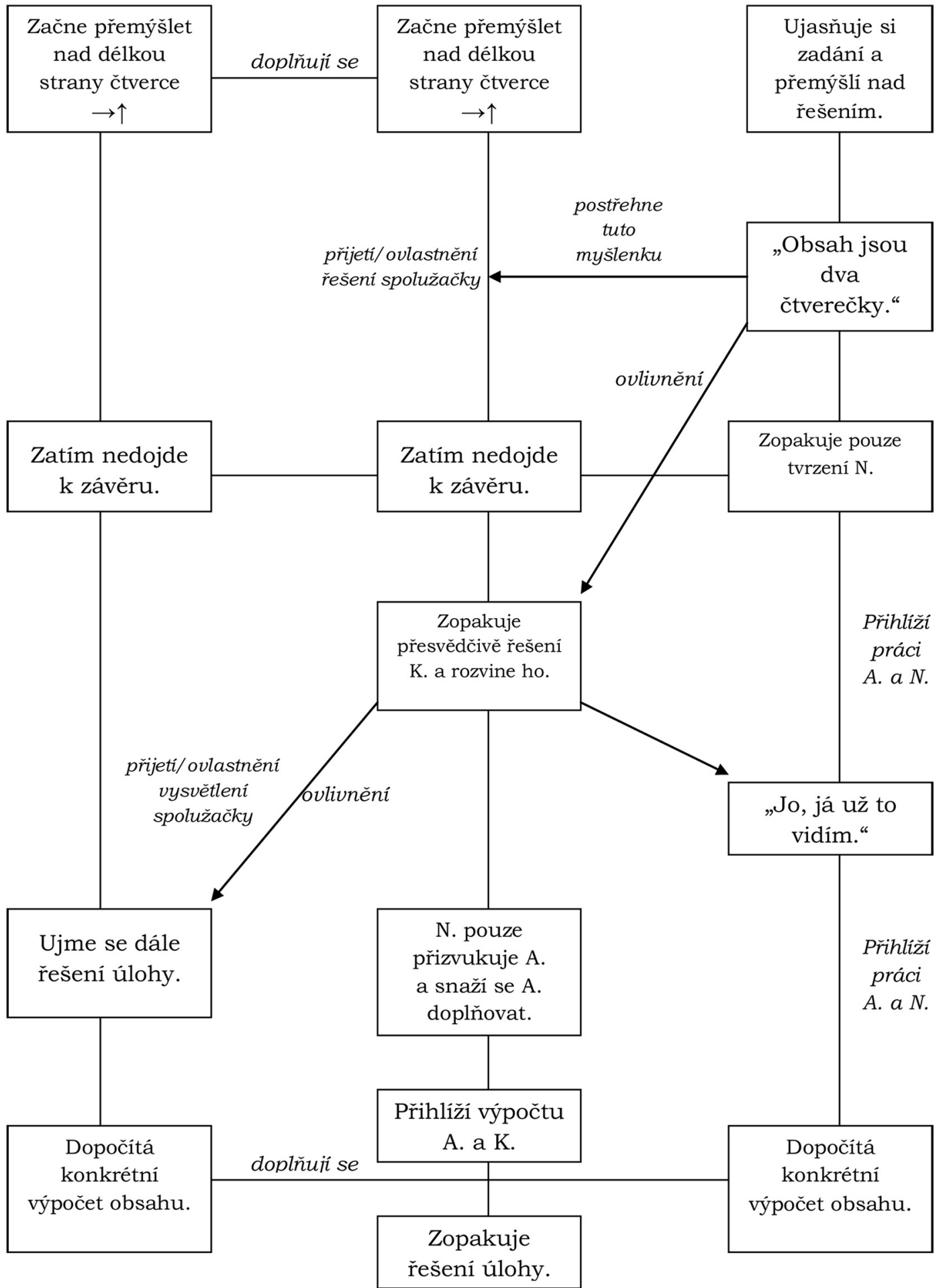

Obr. 10

k vzájemnému ovlivnění a jakým zpo̊sobem (s jakým výsledkem). Ve schématu není uveden vliv experimentátorky, protože ta u práce skupiny v této fázi nebyla, žákyně pracovaly zcela samostatně.

V př́ipadě konstrukce poznatku Zjištěni obsahu čtverce jako součtu obsahů čtyř trojúhelníků a čtverce uvnitř se u skupiny 1 nejprve jednalo o individuální konstrukci poznatku Nely, kdy ji napadla tato strategie: „A ještě bychom tam třeba mohly vypočítat obsahy těch jednotlivých trojúhelníků a pak toho čtverce a pak to sečíst." Nela začala uvažovat nad vzorcem pro výpočet obsahu trojúhelníka a nemohla si 
vzpomenout. Anežka vzorec vyslovila. Klára Nelu upozornila, že musí ale tu výšku trojúhelníka znát. Anežka na to zareagovala: „Výšku si ani počítat nemusíš, protože to je výška v pravoúhlým, že jo, to je ta strana." Klára nesouhlasila s Anežkou: „Ne, ne. Výška je vždycky kolmice k tomuhle tomu." (Ukazuje na přeponu.) Pod výškou si Klára zřejmě představuje další úsečku, která je vepsána do trojúhelníka, ne stranu v pravoúhlém trojúhelníku. Anežka ji však na tuto chybu neupozornila, nebot z hlediska sledovaného cíle se jedná o věc podružnou. Teprve potom došlo ke společné konstrukci poznatku, kdy Nela převzala vysvětlení od Anežky a pokračovala ve svém řešení. O tom, že vysvětlení Anežky Nela pochopila, svědčí i to, že ho byla schopna vysvětlit Kláře. Ta však stále nechápala. I Marcela pochopila, převzala tuto myšlenku a ujala se vysvětlování sama. To je často pozorovaný jev: žák, který právě jistou myšlenku pochopil, má snahu tuto vysvětlit někomu dalšímu, což mu zpravidla umožní hlouběji proniknout do této myšlenky. Dívky se později ke zmíněnému způsobu řešení ještě vrátily - Nela a Anežka spolu tímto zpơsobem dopočítaly úlohu. Nela si vyžádala pomoc od Anežky v označení stran trojúhelníku $v$ a $a$.

Podobným případem, kdy jedna dívka přebrala poznatek od jiné, je konstrukce poznatku Výpočet délky strany mř́žového čtverce pomocí měreni pravítkem. Zpočátku se opět jednalo o individuální konstrukci poznatku, kdy Nelu napadl další způsob řešení úlohy pomocí měření strany pravítkem. Potom se však Anežka ujala psaní a dokončila myšlenku Nely (vypočítala obsah $S=a \cdot a$, kde za $a$ dosadila změřenou délku). Jedná se zde tedy o společnou konstrukci poznatku, kdy Anežka převzala úvodní poznatek Nely.

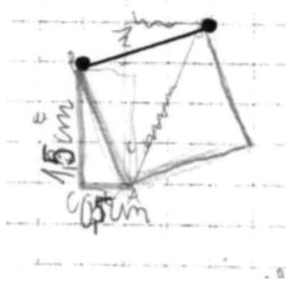

Obr. 11

V řešení úlohy 3 se objevila společná konstrukce poznatku u dívek skupiny 3 . Zatímco Jitka popisovala své řešení v úloze 3a), Bára začala řešit úlohu 3c) z druhého listu (viz obr. 11). Po načrtnutí mřižového čtverce $\rightarrow \rightarrow \rightarrow \uparrow$ si Bára uvědomila, že aby mohla vypočítat obsah čtverce, musí zjistit délku strany čtverce, a to jako délku přepony pravoúhlého trojúhelníku pomocí Pythagorovy věty. Jitka jí to odsouhlasila a pokračovala v popisování řešení úlohy $3 \mathrm{a}$ ), kde právě psala také o výpočtu přepony vzniklého trojúhelníka pomocí Pythagorovy věty. $Z$ videonahrávky je vidět, že Bára zde vyslovila pojem Pythagorovy věty sice jako první, ale Jitka totéž již popisovala ve svém řešení. Bára potřebovala ke své práci prodiskutovat řešení s Jitkou, jedná se tedy o společnou konstrukci poznatku (způsobu řešení úlohy), u Jitky proběhla spíše individuální konstrukce způsobu řešení.

Na závěr došlo ještě ke společné konstrukci poznatku, kdy dívky tvrdily, že řešení, které nalezly, je možné použít vždycky: Jitka připojila vysvětlení, že se to vždycky vypočítá podle Pythagorovy věty, protože se tam pokaždé najde pravoúhlý trojúhelník, jehož přepona je délka strany čtverce (viz obr. 4 v odstavci 4 ). Jitka dokreslila do náčrtku zbývající dva čtverce s obsahy $a^{2}$ a $b^{2}$. Bára uvedla, že $a^{2}+b^{2}=c^{2}$, a tedy $a^{2}+b^{2}=S$. Figura na obr. 4 je pro dívky generickým modelem, který zastupuje figury nad libovolným mřížovým pravoúhlým trojúhelníkem.

Závěrem uved’me, že z hlediska dimenze spolupráce žáků můžeme společnou konstrukci poznatků rozdělit na interakci, při které je spolupráce 
- záměrná - žáci cíleně diskutují o daném problému, nabízejí ostatním své myšlenky ke kritické reflexi a aktivně naslouchají ostatním,

- nezáměrná - jde např. o př́ípad, kdy žák uvažuje nahlas spíše proto, aby si problematiku sám pro sebe ujasnil, avšak jeho poznámka inspiruje řešení jiného žáka.

První typ spolupráce je samozřejmě ve výukovém procesu žádoucí, ovšem i v našich experimentech se ukázalo, že není jednoduché takové interakce dosáhnout. Na to mohla mít vliv jednak určitá pedagogická nezkušenost experimentátorky, ale také to mohly ovlivnit některé osobnostní rysy žáků. Např. žák upřednostňuje přejímání hotových poznatků (je to „jednodušší" a navíc s touto poznávací meta-strategií měl dosud úspěch), nevěnuje tedy energii naslouchání ostatním, ani se nesnaží pochopit jejich úvahy. Zde bychom vůbec nemluvili o konstrukci poznatku, ale o jeho pamětovém uchopení. V našich experimentech (Ulrychová, 2011) se navíc projevila tendence zkoumaných žáků osmiletých gymnázií prosazovat svoje řešení a malá ochota naslouchat úvahám jiných. Je jasné, že učit žáky naslouchat svým spolužákům patří k důležitým složkám práce učitele. K tomu slouží činnosti, při kterých má žák např. vysvětlit svou strategii spolužákovi tak, aby ji ten byl schopen s pochopením vysvětlit někomu dalšímu, nebo pokud učitel vyzývá žáky, aby sami posoudili správnost řešení svých spolužáků, hledali v něm chyby apod.

Procesem konstrukce poznatků v kontextu malých skupin nebo školní třídy se zabývá zejména ve světové literatuře řada autorů. V dalším oddíle se podíváme na výsledky tří výzkumů z hlediska typů konstrukcí, které jsou popsány v tomto článku. ${ }^{10}$

\section{KONSTRUKCE POZNATKŮ U VYBRANÝCH AUTORŮ}

H. Steinbring (2005) hovoří o tzv. interaktivní konstrukci poznatku (,interactivelycreated knowledge“). Tu sice přesně nevymezuje, ale z konkrétních příkladů, které uvádí, se zdá, že se jedná o takovou konstrukci, kterou jsme nazvali společnou. Do interaktivní konstrukce zahrnuje H. Steinbring i učitele. Také společná konstrukce poznatků se uskutečňuje mezi žáky a učitelem s tím, že charakter zapojení učitele je dimenzí této vlastnosti.

H. Steinbring (2005, s. 79) zmiňuje další důležitou dimenzi procesu interaktivní konstrukce poznatků (tzv. křehkost - „fragility“) a dotýká se též problematiky výuky:

Interaktivní konstrukce poznatku je „křehkýc proces v tom smyslu, že jeho úspěch nemůže být vynucen či zaručen. Jako jakýkoli kreativní, konstruktivní čin, je tvorba nové znalosti podmíněna neustálým úsilím vytvořit něco, co dosud nebylo známo a v této podobě neexistovalo. Ale dá se předpokládat, že lze zajistit, aby výuka konstrukce poznatku systematicky řídila a úspěšně organizovala, spíše než aby šlo o volný tvůrčí počin. Ve skutečnosti je možné, stejně jako nezbytné, podpořit proces vyučování a učení se novým matematickým poznatkům takovým způsobem, že úspěch je pravděpodobný a ne zcela nahodilý. Jedním ze způsobů, jak takový proces konstrukce řídit, je prostřednictvím výběru vhodných úloh.

\footnotetext{
${ }^{10}$ Zmínění autoři uvádějí ve svých pracích řadu př́ikladů konstrukcí poznatků žáky, jež zde z prostorových důvodů uvádět nebudeme.
} 
Další tematicky blízký výzkum je práce (Hershkowitz, Hadas, 2007), v níž se hovoří o konstrukci sdílených poznatků („shared knowledge“). Jde o poznatky, které si prostřednictvím společné interakce vytvářejí členové určité skupiny (od několika žáků až po celou třídu). Sdíleným poznatkem pak nazývají takový poznatek, který je skupině společný a který jim umožňuje společně konstruovat další poznatky v dané oblasti. Ve zmíněném výzkumu se však nehovoří o individuální konstrukci poznatků.

Konečně B. Jaworski (1994) mluví o nezávislém kognitivním zpracování (,independent cognitive processing“) v př́padě, kdy žák přijde na nějaký poznatek sám, bez pomoci učitele (i když na základě nějakého podnětu - např. úlohy nebo poznámky, která žáka navedla na souvislosti). Na druhou stranu pak staví intersubjektivní znalost (,intersubjective knowledge“), což je znalost, k níž dochází na základě „vyjednáváni““ („negotiation“) mezi žáky. Bohužel autorka oba konstrukty blíže nepopisuje, není tedy možné zjistit, zda jde o rozlišení podobné tomu, které zde uvádíme.

\section{ZÁvĚR}

Závěrem uvedeme několik obecnějších poznámek.

Důležitým parametrem relativně individuální konstrukce poznatků jsou nepochybně rysy osobnosti žáka. Žák musí být ochoten se problémem zabývat, k čemuž by měl být učitelem systematicky veden a motivován. Měl by mít také dostatečnou míru sebevědomí v matematice, aby mohl pracovat autonomně. Na druhou stranu se několikrát v našich experimentech projevilo, že někteří žáci odmítali např. pomoc prostřednictvím obrázku, jakoby nechtěli do situace proniknout, ale stačil by jim návod, jak postupovat. Druhá z autorek ve své výuce vypozorovala, že se většinou jednalo o žáky, které objevování moc nebaví, kteří se neradi zabývají problémy a spíše čekají, že vše objeví někdo jiný a oni převezmou výsledek. Je možné, že u těchto žáků převládá povrchový přístup k učení (Mareš, 1998, s. 38) a spíše dávají přednost pamětovému záznamu vzorců. Na to mohly mít vliv jejich osobnostní charakteristiky, zcela jistě též jejich předchozí zkušenost s výukou matematiky a úspěšnost při řešení matematických úloh. Je možné, že získali dojem, že na úspěch v matematice stačí znalosti reproduktivního a imitativního charakteru. U takových žáků se může při konstruktivisticky vedené výuce objevit dokonce pocit ohrožení, jak uvádí ve svých závěrech i J. Hanušová (2007) a N. Stehlíková (2004c). V experimentech uvedených v (Ulrychová, 2011) jsme však tento pocit u žáků nepozorovali, což bylo snad dáno i tím, že je druhá z autorek, učitelka matematiky, ve své výuce systematicky vedla k experimentování a práci s chybou. Navíc šlo o žáky osmiletého gymnázia, které matematika zpravidla bavila. Otázka osobnostních charakteristik žáků, které bud' podporují či na druhé straně do jisté míry zabraňují konstruktivisticky vedené výuce, stejně tak jako otázka vlivu žákových předchozích zkušeností s výukou matematiky (napřr. Pesek, Kirshner, 2000), patří mezi ty důležité pro výzkum v didaktice matematiky.

Jako zajímavá se jeví i otázka, jaký typ interakce pravděpodobně vedl ke společné konstrukci (to zkoumá např. práce Hershkowitz, Hadas, 2007). V předloženém výzkumu se ukázalo, že rozhodující byly následující aspekty komunikace mezi žáky: vyžádání pomoci v řešení úlohy, potřeba ujištění položením otázky, přijetí/přivlastnění si vysvětlení spolužačky, prosebný pohled na spolužačku, žádost o přeformulaci otázkou. V průběhu experimentu se vyskytla také taková komunikace, kdy žák řekl něco nahlas ne proto, aby to řekl ostatním, ale aby si to sám ujasnil. To samozřejmě mohlo ostatní ve skupině inspirovat pro vlastní práci. Systematicky jsme však tento 
aspekt konstrukce poznatků nestudovali. Podobně jsme nevěnovali pozornost otázce vlivu složení skupiny na konstrukci poznatků. Tato problematika zůstává otevřena pro další zkoumání.

U obou typů konstrukcí hrál v našich experimentech podstatnou roli učitel, a sice výběrem úloh a př́ipadným směřováním pozornosti žáků $\mathrm{k}$ určitým jevům (např. nápovědami). Tedy v obou př́padech můžeme mluvit o charakteru řízenosti/ovlivnění konstrukce poznatku učitelem (případně jinou třetí osobou), přičemž nevylučujeme ani takový případ, kdy učitel nemá na konstrukci poznatku vliv žádný, a to ani prostřednictvím úlohy (žák si např. úlohu formuluje sám, nebo si zkonstruuje poznatek, který zdánlivě s danou úlohou vůbec nesouvisí - důležité je zde slovo zdánlivě, nebot to, zda se jedná o individuální konstrukci, dokážeme rozhodnout jen z viditelných projevů žáka a z toho, co sám řekne; často však žák není schopen své myšlenkové pochody nějak smysluplně zformulovat). Z výše uvedeného plyne, že hranice mezi (relativně) individuální a společnou konstrukcí poznatku je neostrá a z pohledu vnějšího pozorovatele zpravidla těžko zjistitelná.

Závěrem můžeme konstatovat, že i když jsou závěry, k nimž jsme dospěli, do jisté míry obecněji platné, musíme si být vědomi omezení předloženého výzkumu, který byl limitován počtem zkoumaných žáků i šiřrí tematiky. Už z podstaty zkoumaného problému je jasné, že se musí jednat o výzkum kvalitativní, jehož cílem je poznávat, co se zřejmě děje v mysli žáků při řešení matematických úloh. Ovšem výzkumník nedokáže při nejlepší vůli zrekonstruovat tyto procesy věrně, ale jen s větší či menší dávkou pravděpodobnosti, a to na základě pozorovatelných projevů žáků. V našem případě to bylo na základě toho, co žáci řekli, napsali, nakreslili, jaká zvolili slova, jaké nejazykové prostředky použili při vysvětlování apod.

Článek byl vytvořen v rámci výzkumného záměru MSM 0021620862 Učitelská profese $v$ měnících se požadavcích na vzdělávání.

\section{LITERATURA}

BREEN, Ch. Mathematics Teachers as Researchers. In BISHOP, A. J. et al. (Eds.), Second International Handbook of Mathematics Education. Dordrecht : Kluwer Academic Publishers, 2003, pp. 523-544.

BROUSSEAU, G. Theory of Didactical Situations in Mathematics. Balacheff, N., Cooper, M., Sutherland, R., Warfield, V. (Eds.). Dordrecht : Kluwer Academic Publishers, 1997.

DAVIS, R., B., MAHER, C., A., NODDINGS, N. Constructivist Views on the Teaching and Learning of Mathematics. USA : National Council of Teachers of Mathematics, 1990.

HANUŠOVÁ, J. Cesty učitele ke konstruktivistickým př́stupům. Dizertační práce. Praha: PedF UK v Praze, 2007.

HEJNY, M. Mechanizmus poznávacího procesu. In HEJNÝ, M., NOVOTNÁ, J., STEHLÍKOVÁ, N. (ed.), Dvacet pět kapitol z didaktiky matematiky. Praha: PedF UK v Praze, sv. 1, 2004, s. 23-42.

HEJNY, M., KUŘINA, F. Ditě, škola a matematika. Praha : Portál, 2001.

HERSHKOWITZ, R., HADAS, N. Abstracting Processes, from Individuals' Constructing of Knowledge to a Group's "Shared Knowledge". Mathematics Education Research Journal, Vol. 19, No. 2, 2007, pp. 41-68. 
HERSHKOWITZ, R., SCHWARZ, B., DREYFUS, T. Abstraction in context: Epistemic actions. Journal for Research in Mathematics Education, 32(2), 2001, pp. 195-222.

CHOPIN, M.-P., NOVOTNÁ, J. Contribution of the Theory of Didactical Situations to Mathematics Education: Fundamentals and main concepts. In NOVOTNÁ, J., MORAOVÁ, H. (ed.), Proccedings of SEMT 11. Praha : UK v Praze, PedF, 2011, s. $361-363$.

JANÍK, T. Akční výzkum jako cesta ke zkvalitňování pedagogické praxe. In MAŇÁK, J., ŠVEC, V. (ed.), Cesty pedagogického výzkumu. Brno : Paido, 2004, s. 51-68.

JAWORSKI, B. Investigating Mathematics Teaching. A Constructivist Enquiry. London : The Falmer Press, 1994.

JIROTKOVÁ, D. Cesty ke zkvalitñování výuky geometrie. Praha : PedF UK v Praze, 2010.

MAREŠ, J. Styly učení žáků a studentů. Praha : Portál, 1998.

PESEK, D. D., KIRSHNER, D. Interference of instrumentál instruction in subsequent relations learning. Journal for Research in Mathematics Education, 31(5), 2000, pp. 524-540.

PRŮCHA, J., WALTEROVÁ, E., MAREŠ, J. Pedagogický slovník. Praha : Portál, 1998.

STEHLÍKOVÁ, N. Geometrické transformace analyticky. In HEJNY, M., NOVOTNÁ, J., STEHLÍKOVÁ, N. (ed.), Dvacet pět kapitol z didaktiky matematiky. Praha : PedF UK v Praze, sv. 2, 2004a, s. 279-298.

STEHLÍKOVÁ, N. Konstruktivistické přístupy k vyučování matematice. In HEJNY, M., NOVOTNÁ, J., STEHLÍKOVÁ, N. (ed.), Dvacet pět kapitol z didaktiky matematiky. Praha : PedF UK, sv. 1, 2004b, s. 11-21.

STEHLÍKOVÁ, N. Structural Understanding in Advanced Mathematical Thinking. Praha : PedF UK v Praze, 2004c.

STEHLÍKOVÁ, N. Charakteristika kultury vyučování matematice z pohledu činnosti učitele. In HOŠPESOVÁ, A., STEHLÍKOVÁ, N., TICHÁ, M. (ed.), Cesty zdokonalováni kultury vyučováni matematice. České Budějovice : Jihočeská univerzita, 2007, s. 13-48.

STEINBRING, H. The construction of new mathematical knowledge in classroom interaction: An epistemological perspective. USA : Springer, 2005.

STRAUSS, A., CORBINOVÁ, J. Základy kvalitativního výzkumu. Boskovice : Albert, 1999.

ULRYCHOVÁ, M. Konstrukce poznatků žáky v matematice (na př́kladu Pythagorovy věty). Disertační práce. Praha : PedF UK v Praze, 2011.

doc. RNDr. Nad’a Stehlíková, Ph.D. - E-mail: nada.stehlikova@pedf.cuni.cz Univerzita Karlova v Praze, Pedagogická fakulta, Česká republika

PhDr. Michaela Ulrychová, Ph.D. - E-mail: ulrychova.michaela@centrum.cz Křestanské gymnázium, Praha 10, Česká republika 